\title{
Climate-driven synchrony in otolith growth-increment chronologies for three Bering Sea flatfish species
}

\author{
Mary Elizabeth Matta ${ }^{1, *}$, Bryan A. Black ${ }^{2}$, Thomas K. Wilderbuer ${ }^{1}$ \\ ${ }^{1}$ Resource Ecology and Fisheries Management Division, Alaska Fisheries Science Center, National Marine Fisheries Service, \\ NOAA, 7600 Sand Point Way NE, Seattle, Washington 98115, USA \\ ${ }^{2}$ Hatfield Marine Science Center, Oregon State University, 2030 SE Marine Science Dr., Newport, Oregon 97365, USA
}

\begin{abstract}
Dendrochronology (tree-ring science) techniques were applied to otolith growth increments in 3 flatfish species collected from the eastern Bering Sea: northern rock sole Lepidopsetta polyxystra, yellowfin sole Limanda aspera, and Alaska plaice Pleuronectes quadrituberculatus. Within each species, otoliths were visually crossdated to ensure that the correct calendar year was assigned to each growth increment. Growth-increment widths were measured in each otolith, crossdating was statistically checked, and a single master chronology was generated for each species by averaging measurement time series after age-related growth declines had been removed. The 3 final chronologies spanned 18 to $20 \mathrm{yr}$ and were significantly correlated with each other $(\mathrm{p}<0.001)$, indicating a high level of growth synchrony among species. Final chronologies were compared to annual and monthly climate variables including water temperature, ice cover, the Pacific Decadal Oscillation, and the El Niño Southern Oscillation. Of the climate indices examined, chronologies were most strongly related to summertime eastern Bering Sea bottom temperatures, with $\mathrm{R}^{2}$ values of $0.81,0.61$, and 0.34 for the yellowfin sole, Alaska plaice, and northern rock sole chronologies, respectively. Chronologies were significantly $(\mathrm{p}<0.01)$ and positively related to monthly resolved records of sea surface temperature, though the seasons of the year exhibiting the strongest correlations varied among species. The present study suggests that flatfish growth is strongly influenced by the temperature of the eastern Bering Sea, underscoring the effect of climate on fisheries in a highlatitude ecosystem.
\end{abstract}

KEY WORDS: Sclerochronology $\cdot$ Dendrochronology $\cdot$ Growth $\cdot$ Environment $\cdot$ Otoliths $\cdot$ Flatfishes Eastern Bering Sea

Resale or republication not permitted without written consent of the publisher

\section{INTRODUCTION}

An increasing number of studies have documented that climate variability affects fish growth, productivity, and survival throughout the north Pacific Ocean and the Bering Sea (Beamish 1993, Hollowed \& Wooster 1995, Mantua et al. 1997, Clark et al. 1999, Conners et al. 2002, Wilderbuer et al. 2002). Transitions between warm and cool climate phases have been linked to changes in species composition and biodiversity (Conners et al. 2002, Hoff 2006), spatial distributions (Mueter \& Litzow 2008, Spencer 2008), trophic linkages (Aydin \& Mueter 2007), and ecosystem control (Hunt et al. 2002). In particular, many fish and invertebrate stocks dramatically increased in the Bering Sea during the late 1970s and early 1980s due to a well-documented climate regime shift associated with warmer ocean conditions, demonstrating the relevance of climate to this marine ecosystem (Bakkala 1993, Hollowed \& Wooster 1995, Hare \& Mantua 2000, Conners et al. 2002, Hoff 2006).

Recent studies have utilized tree-ring techniques (dendrochronology) to generate fish otolith growth increment chronologies and estimate the impacts of 
climate on fish populations (Guyette \& Rabeni 1995, Rypel 2009). Final chronologies span multiple decades, provide a value for each calendar year, are exactly dated, and strongly relate to instrumental climate records (Black et al. 2008a,b, Black 2009). For example, $\sim 50 \%$ of the variance in a splitnose rockfish Sebastes diploproa chronology developed for the central California coast was explained by February upwelling intensity (Black et al. 2010). On a broader spatial scale, the splitnose rockfish chronology relates to chronologies of yelloweye rockfish $S$. ruberrimus, Pacific geoduck Panopea generosa, and trees from California through British Columbia, illustrating the pervasive influences of climate from alpine forests through the continental shelf in the Pacific Northwest (Black et al. 2008a,b, Black 2009). Although chronologies have been completed as far north as the border between British Columbia and Alaska, none have been developed to address long-term climate growth relationships in the northern Gulf of Alaska or the Bering Sea.

In the eastern Bering Sea, northern rock sole Lepidopsetta polyxystra, yellowfin sole Limanda aspera, and Alaska plaice Pleuronectes quadrituberculatus are 3 species of single-stock, shallow-water flatfish commonly encountered at depths $<200 \mathrm{~m}$. Yellowfin sole and northern rock sole are both relatively abundant and the subjects of important targeted fisheries, while the less abundant Alaska plaice is usually caught incidentally and seldom retained (Wilderbuer et al. 2007a,b, Wilderbuer \& Nichol 2008). The 3 species share similar life histories and spatial distributions, and their overall diet compositions are comparable, consisting primarily of bivalves, amphipods, polychaetes, and other worms (Aydin et al. 2007). In addition, northern rock sole and yellowfin sole consume a significant percentage of Pacific sand lance Ammodytes hexapterus and euphausiids, respectively (Aydin et al. 2007).

Northern rock sole, yellowfin sole, and, to a lesser extent, Alaska plaice, all experienced significant biomass increases associated with the climate regime shift of the late 1970s (Bakkala 1993, Conners et al. 2002, Hoff 2006). Given this evidence of climate sensitivity, their longevity of $>30 \mathrm{yr}$, and the clarity of their otolith growth increments, all 3 species were identified as strong candidates for chronology development and climate growth analysis. Moreover, mean summer surface temperatures in the Bering Sea are forecast to increase $2^{\circ} \mathrm{C}$ by the year 2050, making it a particularly relevant location for understanding climate impacts on the ecosystem (Hollowed et al. 2009). Thus, the objectives of the present study are to: (1) evaluate the suitability of northern rock sole, yellowfin sole, and Alaska plaice otoliths for chronology development; (2) investigate the degree of growth synchrony within and among the 3 species; and (3) to test the hypothesis that key climatic variables exert control over otolith growth.

\section{MATERIALS AND METHODS}

Alaska plaice and yellowfin sole otoliths were collected in 2007 and 2008, respectively, during summer trawl surveys conducted by the Resource Assessment and Conservation Engineering (RACE) division of NOAA's Alaska Fisheries Science Center (AFSC). Northern rock sole otoliths were collected throughout 2007 by fishery observers in the flatfish trawl fishery. All fish were collected in accordance with standard National Marine Fisheries Service protocols over a wide area of the eastern Bering Sea shelf spanning $\sim 5$ degrees latitude and $\sim 15$ degrees longitude, at depths $<200 \mathrm{~m}$ (Fig. 1). Only otoliths from mature fish were selected for the present study.

Each otolith was transversely sectioned through the core using either a low-speed saw or a scalpel. The cut surface was then exposed to an alcohol flame to enhance the contrast between translucent and opaque growth zones. One complete growth increment (annulus) was defined as the combination of 1 translucent and 1 opaque growth zone. Fish ages were estimated from annulus counts as part of routine age determination by the AFSC Resource Ecology and Fisheries Management Division's Age and Growth Program. Each otolith was then digitally photographed at 16 to 25x magnification using a Leica DFC420 digital camera attached to a Leica MZ95 microscope ${ }^{1}$ (Leica Microsystems).

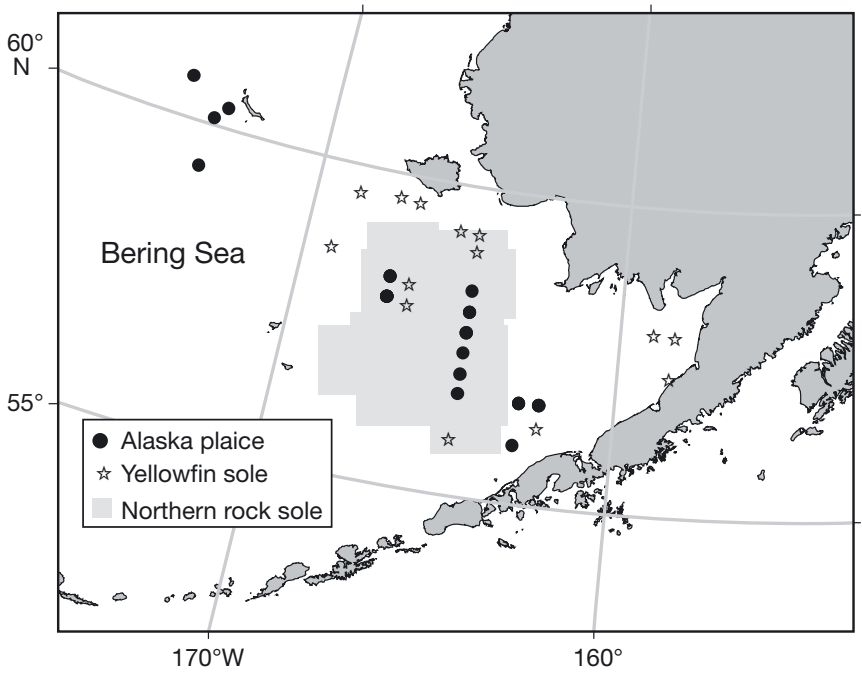

Fig. 1. Specimen collection sites. Fishery-collected northern rock sole are not shown as point data due to confidentiality reasons 
Once photographed, otoliths were visually crossdated to ensure that the correct calendar year was assigned to each growth increment. A fundamental technique of dendrochronology, crossdating is based on the assumption that some aspect of climate limits growth, and as climate varies over time, it induces a synchronous growth pattern in all individuals from a given species and region (Douglass 1920, Fritts 1976, Yamaguchi 1991, Stokes \& Smiley 1996). While individual variations in growth may exist, the overall shared growth pattern reflects the environmental signal. Crossdating is the process of matching synchronous growth patterns among individuals, beginning at the marginal increment formed during the known year of capture and proceeding toward the core. If a growth increment has been missed or falsely added, the growth pattern for that individual will be offset by a year relative to that in the other specimens, thereby identifying the mistake (see Black et al. 2005, 2008b, Rypel et al. 2008 for crossdating procedures in aquatic or-

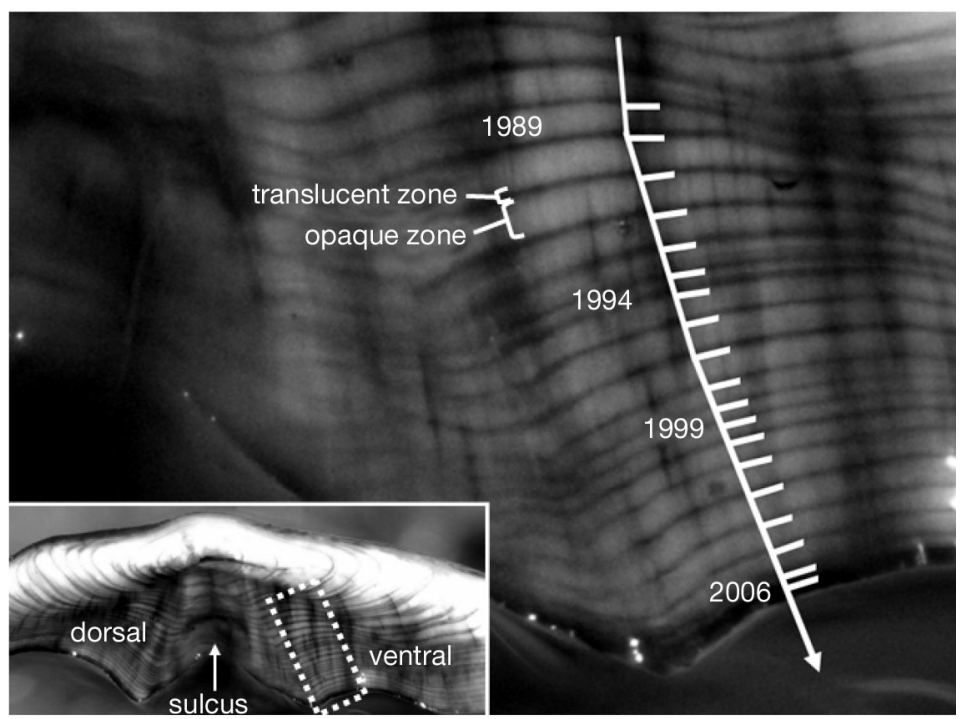

Fig. 2. Limanda aspera. Yellowfin sole otolith cross-section viewed with reflected light and annotated with measurements. Increments that were consistently narrow across specimens are labeled with corresponding calendar years. Inset: whole otolith, measurement axis region bounded by dashed lines ganisms). At no time did we 'force' crossdating on an otolith, and corrections were only made when the accidentally missed or falsely added increment was obviously visible upon reinspection of the specimen. Only otoliths $15 \mathrm{yr}$ or older with clear growth increments were retained for crossdating to ensure measurement time series would be long enough for detrending. No specimens were excluded from further analysis based on the results of crossdating.

After visual crossdating, the width of each growth increment was measured using ImagePro Plus v. 5.1 image processing software (Media Cybernetics) (Fig. 2). First, we attempted to locate the axis of measurement as consistently as possible while considering the ultimate goal of capturing relative changes in interannual growth. Only a small portion of the otolith cross section contained clear, parallel, undistorted increments suitable for measurement. This region was usually located along the ventral side of the sulcus, a groove on the proximal side of the otolith (Fig. 2), though the dorsal side was of superior clarity in $\sim 10 \%$ of the specimens. The axis of measurement was drawn parallel to the direction of growth (i.e. perpendicular to growth increment boundaries), after which the growth increments were delineated. One complete increment was defined as the distance from the distal side of the previous year's translucent zone to the distal side of the current year's translucent zone. Due to rapid ontogenetic changes in growth rates that distorted increment widths in the

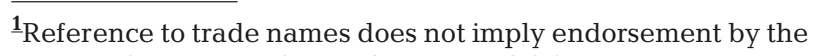
National Marine Fisheries Service, NOAA region of the measurement axis, the innermost 3 to 5 increments of each otolith were not measured.

Visual crossdating was statistically checked using the International Tree-Ring Data Bank Program Library quality-control software COFECHA (Holmes 1983, Grissino-Mayer 2001). In COFECHA, each otolith measurement time series was fit with a cubic spline with a $50 \%$ frequency cutoff set at 22 yr (Black et al. 2005, Black 2009). Measurements were divided by the values predicted by the spline, thereby removing longterm trends and standardizing each time series to a mean of 1. Any remaining autocorrelation was removed via autoregressive modeling, which further enhanced high-frequency (year-to-year) growth patterns. Each standardized time series was then correlated with the average of all other standardized time series, the average of which was reported as the series intercorrelation. Any time series with non-significant values ( $p<0.01$ ) was visually inspected for errors. COFECHA was also used to calculate the mean sensitivity, an index of high-frequency (year-to-year) variability among pairs of successive increments that ranges from a minimum of 0 (a pair of increments of the same width) to a maximum of 1 (a pair in which one width is 0) (Fritts 1976). Overall, cross-correlating high-frequency growth patterns among individuals statistically mimicked the visual crossdating process and provided an extra level of dating verification. COFECHA was used to screen the data for potential mistakes, but all decisions about crossdating were ultimately made by visually inspecting each individual. 
To develop master chronologies for climate analysis, each set of the original growth increment measurements was fit with a negative exponential function and divided by the values predicted. This detrending process contrasts with detrending for the purpose of statistical crossdating in COFECHA, in which highly flexible cubic splines were employed to extract only highfrequency growth patterns. By using much more rigid negative exponential functions, age-related growth declines in the measurement time series were removed while preserving as much environmentally-induced variability as possible. Within each species, measurement time series detrended with negative exponential functions were averaged to calculate a final master chronology. Measurement time series with at least 10 observations were used for chronology development to ensure proper fit by negative exponential functions, and only those portions of the master chronology with at least 6 individuals contributing were retained to ensure adequate signal-to-noise ratios.

Final chronologies were compared among species and with a number of climate indices. Average annual eastern Bering Sea summer bottom temperatures were obtained from bottom trawl surveys conducted by the AFSC RACE division (NOAA 2009). Sea surface temperatures (SSTs) were obtained from 2 sources: (1) in situ and satellite records averaged over the area 54.3 to $60^{\circ} \mathrm{N}$, 161.2 to $172.5^{\circ} \mathrm{W}$, during the month of May (NOAA 2009), and (2) monthly interpolated Hadley sea surface temperature (HadISST) data for the region 55 to $60^{\circ} \mathrm{N}, 160$ to $170^{\circ} \mathrm{W}$ (Rayner et al. 2003), obtained through the Royal Netherlands Institute of Meteorology (KNMI) Climate Explorer (KNMI 2009). Each chronology was correlated with the sea ice cover index, defined as the average sea ice concentration from 1 January through 31 May for the area 56 to $58^{\circ} \mathrm{N}, 163$ to $165^{\circ} \mathrm{W}$ (NOAA 2009). Chronologies were also correlated with monthly averages of the Pacific Decadal Oscillation (PDO), the leading principal component of SSTs for the North Pacific poleward of $20^{\circ} \mathrm{N}$ latitude (Mantua et al. 1997), as well as with monthly averages of the Multivariate El Niño Southern Oscillation (ENSO) Index (MEI), the leading principal component of 6 marine and atmospheric variables in the tropical Pacific (Wolter \& Timlin 1998). PDO values were obtained from the University of Washington Joint Institute for the Study of the Atmosphere and Ocean (JISAO 2009), while MEI data were obtained through the Physical Sciences Division of NOAA's Earth System Research Laboratory (NOAA/ESRL 2009). Monthly averages were used for the MEI, PDO, and HadISST data, considering that climate during 1 mo or season of the year could impart a disproportionately large effect on annual flatfish growth. For all monthly resolved variables, correlations were performed over a 19 mo win- dow that included 3 mo from the previous calendar year and 4 mo from the subsequent calendar year. Such a window was necessary considering that growth increments may continue to form early in the subsequent calendar year, lags could occur in the expression of climate impacts in growth, and ENSO signals can require as many as 14 mo to reach the Bering Sea (Hollowed et al. 2001).

\section{RESULTS}

Otoliths from 29 Alaska plaice $($ male $=8$, female $=21$ ), 28 northern rock sole (male $=4$, female $=24$ ), and 22 yellowfin sole $($ male $=10$, female $=11$ ) were examined . One distorted yellowfin sole otolith did not share the general morphological shape of the other otoliths, likely due to a developmental deficiency, and was omitted from further analysis. All remaining otoliths were included in the final chronologies.

Based on annulus counts, specimens ranged in age from 16 to 34 yr for Alaska plaice, 15 to 23 yr for northern rock sole, and 18 to $34 \mathrm{yr}$ for yellowfin sole. Age estimates derived from annulus counts agreed with those derived from crossdating in $83 \%$ of the Alaska plaice otoliths, $94 \%$ of the northern rock sole otoliths, and $100 \%$ of the yellowfin sole otoliths. Crossdating added an extra year to the annulus-derived age estimates of 5 Alaska plaice and 2 northern rock sole otoliths. In all cases, age estimate discrepancies were related to difficulty in interpreting the last increment on the otolith edge during routine age determination.

Growth was highly synchronous not only within but also among species. For example, the opaque growth zone corresponding to the year 1999 proved to be a strong morphological marker and was consistently narrow in individuals of all 3 species. Other conspicuously narrow years included 1989, 1992, 1994, 1997, 2001, and 2006, while 1998 and 2003 were conspicuously wide.

Reflecting the high degree to which growth was synchronized within species, the interseries correlations ranged from a low of 0.59 in Alaska plaice to a high of 0.66 in yellowfin sole (Table 1). Mean sensitivities were also very similar among species, with values between 0.23 and 0.26 , and the average length of measurement time series used in the master chronologies ranged from 14.2 to $16.9 \mathrm{yr}$ (Table 1). Master chronology length spanned $18 \mathrm{yr}$ for northern rock sole and yellowfin sole and 20 yr for Alaska plaice. First-order autocorrelation was not significant, with a maximum value of 0.30 for northern rock sole (Table 1). The master chronologies of all 3 species strongly and positively related with one another; for example, the correlation coefficient between yellowfin sole and Alaska plaice was 0.90 (Table 2). 
Table 1. Flatfish chronology properties. Mean sensitivity: index of high-frequency variability. Interseries correlation: average correlation between each detrended time series (using a 15 yr cubic spline) and the average of all other detrended measurement time series. Mean series length: average length of the measurement time series used in the chronology. AK Pl: Alaska plaice Pleuronectes quadrituberculatus; NRS: northern rock sole Lepidopsetta polyxystra; YFS: yellowfin sole Limanda aspera; n: number of otolith measurement time series used to develop each final chronology

\begin{tabular}{|lccccc|}
\hline Chronology & $\mathrm{n}$ & $\begin{array}{c}\text { Mean } \\
\text { sensitivity }\end{array}$ & $\begin{array}{c}\text { Interseries } \\
\text { correlation }\end{array}$ & $\begin{array}{c}\text { Mean series } \\
\text { length }(\mathrm{yr})\end{array}$ & $\begin{array}{c}\text { First-order } \\
\text { autocorrelation }\end{array}$ \\
\hline AK Pl & 29 & 0.24 & 0.59 & 15.2 & -0.02 \\
NRS & 28 & 0.23 & 0.61 & 14.2 & 0.30 \\
YFS & 21 & 0.26 & 0.66 & 16.9 & 0.26 \\
\hline
\end{tabular}

Measurement time series followed only modest agerelated growth declines (Fig. 3A) and were well fit by negative exponential functions. Overall, the detrending process reduced variability among samples and enhanced the population-wide growth pattern (Fig. 3B). All 3 master chronologies were strongly correlated with instrumental records of May SSTs, and to an even greater degree, summer bottom temperatures (Table 2, Fig. 3C). The relationship between master chronology growth-increment width and bottom temperature was linear and positive, with $\mathrm{R}^{2}$ values ranging from 0.34 to 0.81 (Fig. 4). An analysis of covariance (ANCOVA) indicated that the regression line slopes did not significantly differ among the 3 species (df $=2, F=0.13, p=0.88$ ). Consistent with their positive relationships to temperature, all 3 chronologies were negatively correlated with sea ice cover (Table 2).

The relationships between the chronologies and monthly resolved Hadley SST data corroborated strongly positive relationships between growth and bottom temperature (Fig. 5A). However, the seasonality of climate response differed among species. Yellowfin sole growth related most strongly to temperature, with significant relationships beginning in June and persisting for 9 mo through January of the following calendar year (Fig. 5A). Alaska plaice showed a similar response, although correlations were weaker (Fig. 5A). By contrast, peak correlations for northern rock sole occurred very late in the growing season, strongest from December of the current calendar year through February of the following calendar year (Fig. 5A). Relationships between master chronologies and the PDO were weaker, but also highlighted the seasonal difference between northern rock sole and the other 2 species (Fig. 5B). Although consistently positive, no correlations with MEI were significant at the $\mathrm{p}<0.05$ level (Table 2).
Overall, positive correlations between flatfish chronologies and temperature, the PDO, and MEI indicated that warm conditions were favorable for growth.

\section{DISCUSSION}

All 3 master chronologies were strongly correlated with one another, and species' relationships with climate variables were remarkably consistent. Such coherent growth patterns and comparable climate growth relationships likely reflect similarities in the ecology of these flatfish species. All 3 species share similar diets and appear to move offshore during the winter months to avoid colder bottom temperatures and sea ice cover (Wilderbuer et al. 1992, Bakkala 1993). Furthermore, the Bering Sea populations of all 3 species increased in abundance during warming trends associated with the late-1970s regime shift (Bakkala 1993, Hare \& Mantua 2000, Conners et al. 2002, Hoff 2006). Lastly, laboratory experiments have demonstrated that somatic growth of northern rock sole increases with temperature (Hurst \& Abookire 2006), consistent with the relationships between climate and master chronologies noted in the present study.

The degree of growth synchrony within each of the 3 flatfish species was comparable to that observed in the growth increment chronologies of other species in the northeast Pacific. Indeed, values for series intercorrelation, an index of synchrony among individuals contributing to a chronology, were similar to those for rockfish ( 0.55), trees (between 0.55 and 0.70), and Pacific geoduck $(\sim 0.70)$ in the Pacific Northwest and Alaska (Black et al. 2008a,b, Black 2009). As in these other species, some aspect of the physical environment strongly affected flatfish growth in the region sampled for chronology development. However, a notable attribute of flatfish growth in the Bering Sea was its synchrony across a particularly large geographic region.
Table 2. Correlation matrix of relationships between master chronologies and environmental indices. Significant correlations $(p<0.05)$ in bold. B Temp: mean summer bottom temperature; May SST: mean May sea surface temperature; Ice: ice cover index in the Bering Sea. AK Pl, NRS, YFS: see Table 1

\begin{tabular}{|lcccccc|} 
& AK Pl & NRS & YFS & B temp & May SST & Ice \\
\hline AK Pl & 1.00 & - & - & - & - & - \\
NRS & $\mathbf{0 . 7 1}$ & 1.00 & - & - & - & - \\
YFS & $\mathbf{0 . 9 0}$ & $\mathbf{0 . 7 6}$ & 1.00 & - & - & - \\
B temp & $\mathbf{0 . 7 8}$ & $\mathbf{0 . 5 9}$ & $\mathbf{0 . 9 0}$ & 1.00 & - & - \\
May SST & $\mathbf{0 . 7 8}$ & $\mathbf{0 . 7 1}$ & $\mathbf{0 . 8 5}$ & $\mathbf{0 . 8 4}$ & 1.00 & - \\
Ice & $\mathbf{- 0 . 5 8}$ & $\mathbf{- 0 . 5 7}$ & $\mathbf{- 0 . 6 5}$ & $\mathbf{- 0 . 6 5}$ & $\mathbf{- 0 . 7 3}$ & 1.00 \\
\hline
\end{tabular}


For example, in the California Current Ecosystem, otoliths of splitnose rockfish from $\sim 36$ to $39^{\circ} \mathrm{N}$ latitude do not strongly crossdate with samples obtained above $\sim 42^{\circ} \mathrm{N}$ latitude (Black et al. 2005). Along the British Columbia coast, Pacific geoduck may not crossdate over distances of tens of $\mathrm{km}$ (Black et al. 2008b). By contrast, flatfish otoliths collected near St. Matthew Island in the northern Bering Sea crossdated with those collected in Bristol Bay, a distance of over
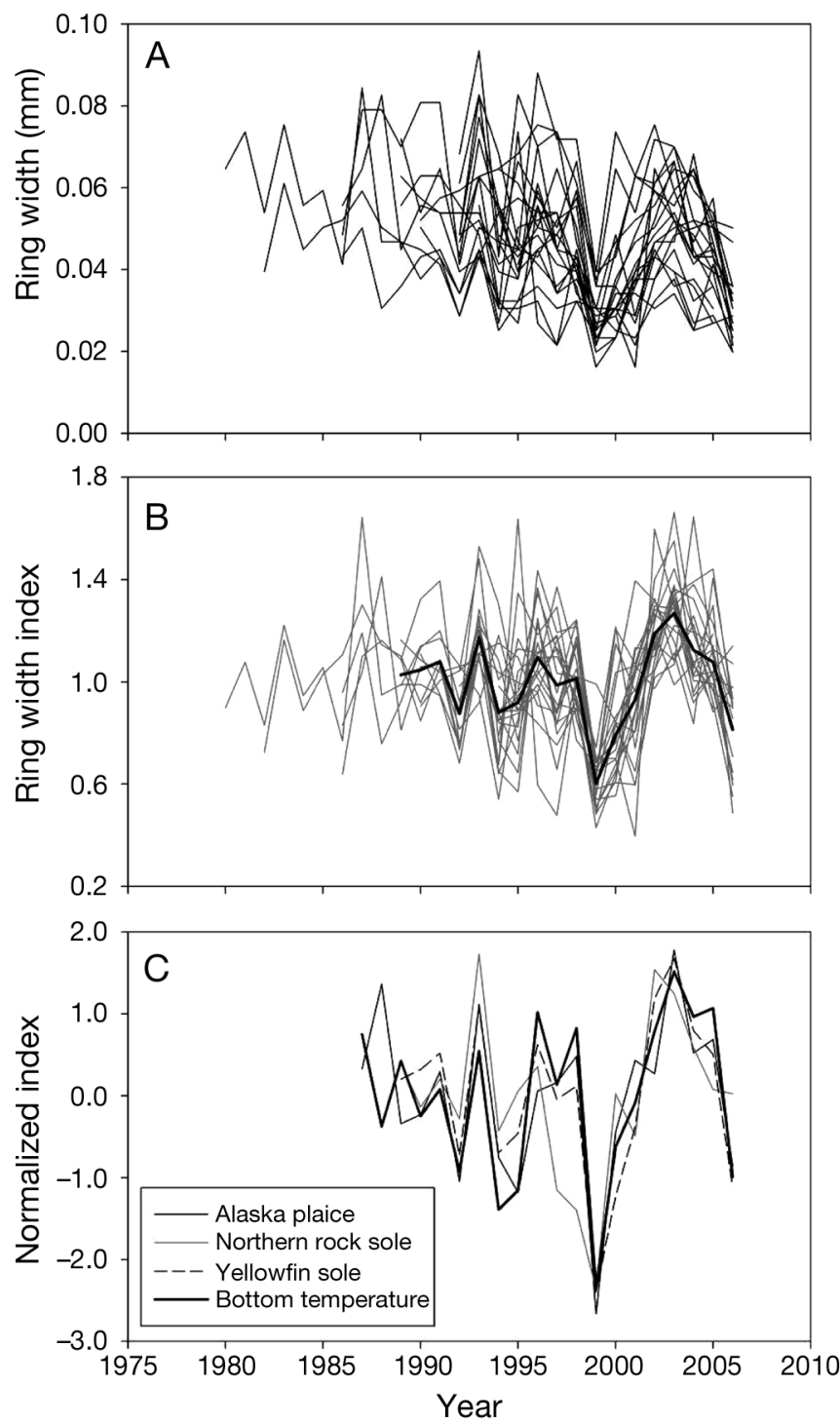

Fig. 3. Limanda aspera, Pleuronectes quadrituberculatus and Lepidopsetta polyxystra. (A) Growth-increment width measurements for 21 yellowfin sole otoliths. (B) Yellowfin sole growth-increment widths after detrending with negative exponential curves; the average of detrended measurement time series (the master chronology) is in black. The master chronology is only calculated for years with $>6$ otoliths contributing. (C) Master chronologies for Alaska plaice, northern rock sole, and yellowfin sole and time series of mean summer bottom temperature for the southeastern Bering Sea. All data are normalized to a mean of 0 and standard deviation of 1
$500 \mathrm{n}$ miles. Such synchrony within and among species suggests that interannual climate variability is at least somewhat homogenous across large regions of the eastern Bering Sea shelf.

Species that make extensive movements based on temperature preference would be expected to have relatively low correlations between otolith growth increments and temperature-related climate variables. In contrast, species that maintain site fidelity despite thermal variability would be better candidates for temperature-dependent growth modeling. The 3 flatfish species considered in this analysis all make only modest movements during the summertime feeding season to avoid extreme temperatures and are consequently vulnerable to changes in growth due to climate variability. The summers of 1999 and 2003 were respectively the coldest and warmest summers in the time series examined in the present study. All 3 flatfish species demonstrated sensitivity to the extreme summer bottom temperatures experienced in 1999 and 2003, evidenced by narrow otolith growth-increment widths. This could indicate that these species do not make broad-scale movements during the growing season, or at least not large enough to escape regional climate conditions.

Temperature-dependent growth is well documented in marine fish (Pauly 1980, Hagen \& Quinn 1991, Brander 1995, Pörtner et al. 2001) and can have a significant effect on growth patterns of fish living in environments that exhibit large fluctuations in water temperature. In the eastern Bering Sea, there is great potential for large interannual differences in summertime bottom water temperatures due to the cold pool phenomenon. The cold pool is a body of subsurface sea ice meltwater $\left(<2^{\circ} \mathrm{C}\right)$ trapped during spring stratification; its size is closely associated with the annual sea ice extent (Stabeno et al. 2001). This cold water persists throughout the summer when flatfish species are broadly distributed over the continental shelf for feeding. Spencer (2008) examined eastern Bering Sea summer trawl survey data from 1982 to 2006 to determine how temporal changes in the distributions of 6 flatfish species are related to annual changes in the location of the cold pool. His results indicated that the distribution of northern rock sole shifts to the north and northwest during relatively warm years in response to water temperature, whereas Alaska plaice and yellowfin sole exhibit only slight distributional changes that do not correspond to environmental conditions, suggesting these species do not seek out preferred temperatures.

Northern rock sole growth was more loosely correlated with bottom temperature (Table 2, Fig. 3C, Fig. 4) than was growth of either yellowfin sole or Alaska plaice. A significant decrease in northern rock sole mean length at age (Walters \& Wilderbuer 2000), con- 
current with population increase and northwest expansion (Spencer 2008), has been observed. This density-dependent growth response may be partially responsible for the lack of fit of the northern rock sole master chronology to bottom temperature from 1996 to 1998 (Fig. 3C), the years of peak northern rock sole biomass (Wilderbuer \& Nichol 2008). These results suggest that both density-dependent and densityindependent factors may play a role in the response of northern rock sole growth to bottom water temperature. In addition, temperature may be associated with lower trophic level productivity, creating indirect effects between growth and the physical environment. Despite the positive relationship between temperature and growth, the mechanisms underlying these climategrowth relationships were not determined in the present study. Warm temperatures may increase metabolic rates, favor lower trophic level productivity and food supplies, or both.

Comparisons between master chronologies and monthly sea surface temperatures also revealed marked differences among the species. Unlike Alaska plaice and yellowfin sole, the peak sensitivity of northern rock sole to SST occurs late in the calendar year. This species may benefit from an extended growing season induced by unusually warm autumn and winter months. Relationships between chronologies and monthly resolved PDO data also demonstrated seasonal differences between northern rock sole and the other 2 species, and showed the degree to which broad-scale climatic processes affect growth of these species in the Bering Sea. Notably, chronologies did not relate to MEI, a measure of the ENSO, even when lagged. Though the impacts of ENSO have been widely observed in the north Pacific, especially in the California Current Ecosystem (Wells et al. 2008, Schroeder et al. 2009), the PDO appears to have much more relevance at higher latitudes.

The chronologies developed in the present study are, to our knowledge, the most northerly yet developed for any fish species. The present study clearly demonstrates the effect of climate across similar species and large spatial scales in the Bering Sea, reinforcing previous research that indicates positive relationships between flatfish populations and temperature. Future efforts could include extending the 3 flatfish chronologies farther back in time using archived otoliths. Spanning the 1970, Bering Sea regime shift and better quantifying the impacts of low-frequency climate variability would be particularly important. While this regime shift resulted in the invasion and rapid population increase of many groundfish species across the eastern Bering Sea shelf, including shallow-water flatfishes, other species such as Greenland halibut Reinhardtius hippoglossoides subsequently declined

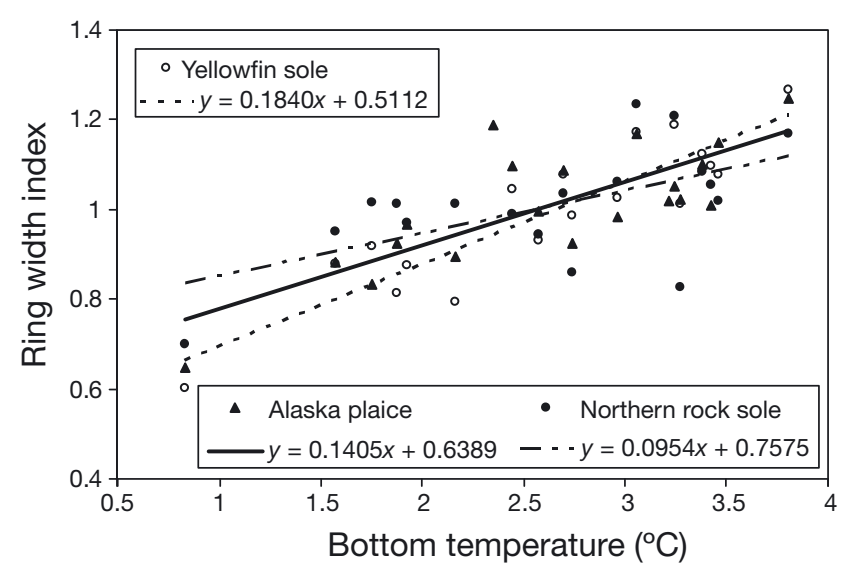

Fig. 4. Linear regressions of mean summer bottom temperature in the southeastern Bering Sea on otolith master chronologies of Alaska plaice $\left(\mathrm{R}^{2}=0.61\right)$, northern rock sole $\left(R^{2}=0.34\right)$, and yellowfin sole $\left(R^{2}=0.81\right)$

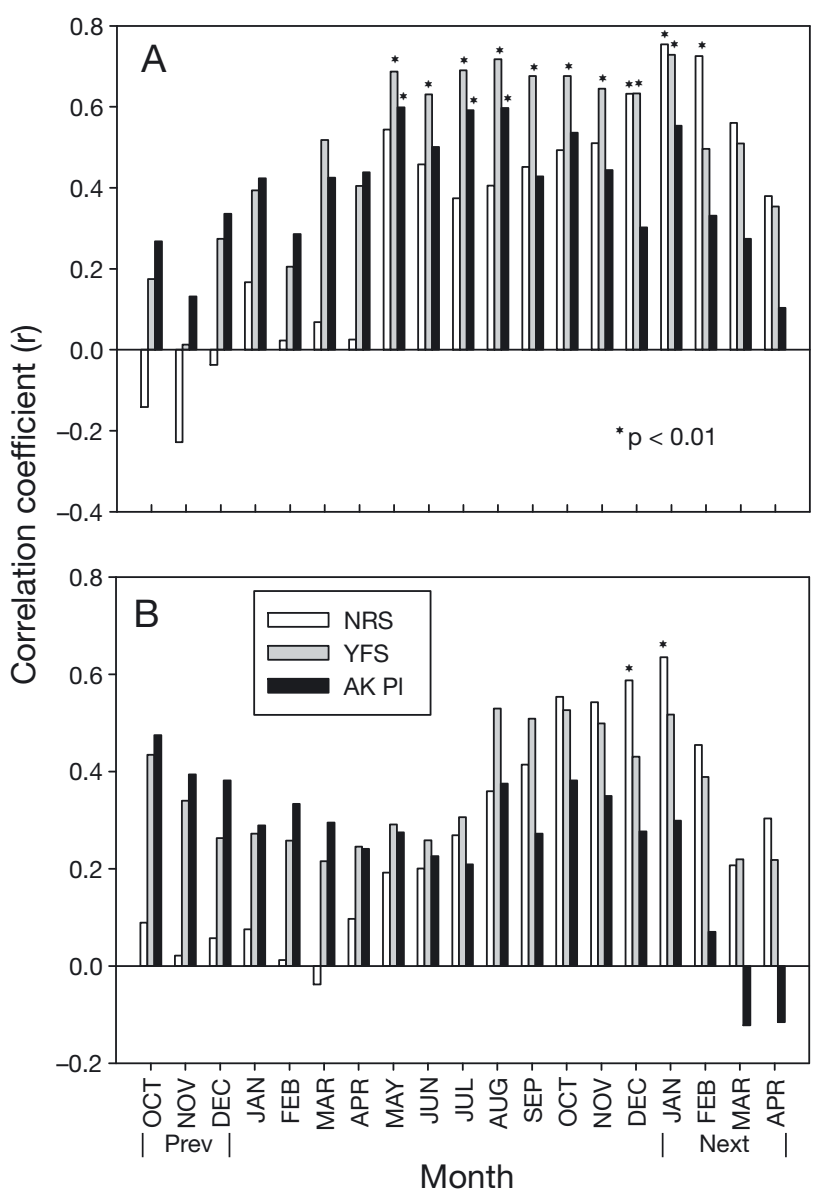

Fig. 5. Correlations between each master chronology and (A) monthly interpolated Hadley sea surface temperatures (HadISST) for the Bering Sea (55 to $60^{\circ} \mathrm{N}, 160$ to $170^{\circ} \mathrm{W}$ ), and (B) average monthly Pacific Decadal Oscillation. AK Pl, NRS, YFS: see Table $1 .{ }^{*}$ Correlation significant at the $p<0.01$ level 
(Overland \& Stabeno 2004). Chronologies developed from the otoliths of species that have experienced dramatic fluctuations in stock abundance may elucidate the effects of climate transitions upon growth and community structure, providing a more holistic ecosystemlevel perspective of climate impacts.

Acknowledgements. We thank the Age and Growth Program of the NOAA-AFSC for providing equipment and supplies. Many thanks to the RACE and Fisheries Monitoring Analysis divisions of the AFSC for otolith collections. Anne Hollowed, Paul Spencer, Thomas Helser, and 4 anonymous reviewers provided valuable comments on earlier drafts of this manuscript. B.A.B. was supported by a grant from the NOAA National Marine Fisheries Service Alaska Fisheries Science Center and the NOAA Fisheries and the Environment (FATE) program.

\section{LITERATURE CITED}

Aydin K, Mueter F (2007) The Bering Sea-a dynamic food web perspective. Deep-Sea Res II 54:2501-2525

Aydin K, Gaichas S, Ortiz I, Kinzey D, Friday N (2007) A comparison of the Bering Sea, Gulf of Alaska, and Aleutian Islands large marine ecosystems through food web modeling. US Department of Commerce, NOAA Tech Memo NMFS-AFSC-178

Bakkala RG (1993) Structure and historical changes in the groundfish complex of the eastern Bering Sea. NOAA Tech Rep NMFS 114

> Beamish RJ (1993) Climate and exceptional fish production off the west coast of North America. Can J Fish Aquat Sci 50:2270-2291

Black BA (2009) Climate-driven synchrony across tree, bivalve, and rockfish growth-increment chronologies of the northeast Pacific. Mar Ecol Prog Ser 378:37-46

Black BA, Boehlert GW, Yoklavich MM (2005) Using tree-ring crossdating techniques to validate annual growth increments in long-lived fishes. Can J Fish Aquat Sci 62: $2277-2284$

Black BA, Boehlert GW, Yoklavich MM (2008a) Establishing climate-growth relationships for yelloweye rockfish (Sebastes ruberrimus) in the northeast Pacific using a dendrochronological approach. Fish Oceanogr 17:368-379

Black BA, Gillespie DC, MacLellan SE, Hand CM (2008b) Establishing highly accurate production-age data using the tree-ring technique of crossdating: a case study for Pacific geoduck (Panopea abrupta). Can J Fish Aquat Sci 65:2572-2578

Black BA, Schroeder I, Sydeman WJ, Bograd S, Lawson P (2010) Wintertime ocean conditions synchronize rockfish growth and seabird reproduction in the central California Current Ecosystem. Can J Fish Aquat Sci 67:1149-1158

Brander KM (1995) The effect of temperature on growth of Atlantic cod (Gadus morhua L.). ICES J Mar Sci 52:1-10

> Clark WG, Hare SR, Parma AM, Sullivan PJ, Trumble RJ (1999) Decadal changes in growth and recruitment of Pacific halibut (Hippoglossus stenolepis). Can J Fish Aquat Sci 56:242-252

> Conners ME, Hollowed AB, Brown E (2002) Retrospective analysis of Bering Sea bottom trawl surveys: regime shift and ecosystem reorganization. Prog Oceanogr 55:209-222

> Douglass AE (1920) Evidence of climate effects in the annual rings of trees. Ecology 1:24-32

Fritts HC (1976) Tree rings and climate. Academic Press, New York, NY
Grissino-Mayer HD (2001) Evaluating crossdating accuracy: a manual and tutorial for the computer program COFECHA. Tree-Ring Res 57:205-221

> Guyette RP, Rabeni CF (1995) Climate response among growth increments of fish and trees. Oecologia 104: 272-279

Hagen PT, Quinn TJ II (1991) Long-term growth dynamics of young Pacific halibut: evidence of temperature-induced variation. Fish Res 11:283-306

Hare SR, Mantua NJ (2000) Empirical evidence for North Pacific regime shifts in 1977 and 1989. Prog Oceanogr 47: 103-145

Hoff GR (2006) Biodiversity as an index of regime shift in the eastern Bering Sea. Fish Bull 104:226-237

Hollowed AB, Wooster WS (1995) Decadal-scale variation in the eastern subarctic Pacific: II. Response of northeast Pacific fish stocks. In: Beamish RJ (ed) Climate change and northern fish populations. Can Spec Publ Fish Aquat Sci 121:373-385

> Hollowed AB, Hare SR, Wooster WS (2001) Pacific Basin climate variability and patterns of northeast Pacific marine fish production. Prog Oceanogr 49:257-282

Hollowed AB, Bond NA, Wilderbuer TK, Stockhausen WT, A'mar ZT, Beamish RJ, Overland JE, Schirripa MK (2009) A framework for modelling fish and shellfish responses to future climate change. ICES J Mar Sci 66:1584-1594

Holmes RL (1983) Computer-assisted quality control in treering dating and measurement. Tree-Ring Bull 43:69-78

> Hunt GL Jr., Stabeno P, Walters G, Sinclair E, Brodeur RD, Napp JM, Bond NA (2002) Climate change and control of the southeastern Bering Sea pelagic ecosystem. Deep-Sea Res II 49:5821-5853

> Hurst TP, Abookire AA (2006) Temporal and spatial variation in potential and realized growth rates of age- 0 year northern rock sole. J Fish Biol 68:905-919

JISAO (2009) The Pacific Decadal Oscillation. Available at jisao.washington.edu/pdo

KNMI (2009) The Royal Netherlands Institute of Meteorology (KNMI) Climate Explorer. Available at climexp.knmi.nl

> Mantua NJ, Hare SR, Zhang Y, Wallace JM, Francis RC (1997) A Pacific interdecadal climate oscillation with impacts on salmon production. Bull Am Meteorol Soc 78:1069-1079

Mueter FJ, Litzow MA (2008) Sea ice retreat alters the biogeography of the Bering Sea continental shelf. Ecol Appl 18:309-320

NOAA (2009) Bering Sea climate. Available at www.beringclimate.noaa.gov

NOAA/ESRL (2009) Multivariate ENSO Index (MEI). Available at www.cdc.noaa.gov/people/klaus.wolter/MEI

Overland JE, Stabeno PJ (2004) Is the climate of the Bering Sea warming and affecting the ecosystem? Eos Trans AGU 85:309-316

Pauly D (1980) On the interrelationships between natural mortality, growth parameters, and mean environmental temperature in 175 fish stocks. ICES J Mar Sci 39: $175-192$

> Pörtner HO, Berdal B, Blust R, Brix O and others (2001) Climate induced temperature effects on growth performance, fecundity and recruitment in marine fish: developing a hypothesis for cause and effect relationships in Atlantic cod (Gadus morhua) and common eelpout (Zoarces viviparous). Cont Shelf Res 21:1975-1997

- Rayner NA, Parker DE, Horton EB, Folland CK and others (2003) Global analysis of sea surface temperature, sea ice, and night marine air temperature since late nineteenth century. J Geophys Res 108(D14):4407. doi:10.1029/2002 JD002670

Rypel AL (2009) Climate-growth relationships for largemouth 
bass (Micropterus salmoides) across three southeastern USA states. Ecol Freshw Fish 18:620-628

Rypel AL, Haag WR, Findlay RH (2008) Validation of annual growth rings in freshwater mussel shells using cross dating. Can J Fish Aquat Sci 65:2224-2232

Schroeder I, Sydeman WJ, Sarkar N, Bograd SJ, Schwing FB (2009) Winter pre-conditioning of seabird phenology in the California Current. Mar Ecol Prog Ser 393:211-223

Spencer PD (2008) Density-independent and density-dependent factors affecting temporal changes in spatial distributions of eastern Bering Sea flatfish. Fish Oceanogr 17: $396-410$

Stabeno PJ, Bond NA, Kackel NB, Salo SA, Schumacher JD (2001) On the temporal variability of the physical environment over the south-eastern Bering Sea. Fish Oceanogr 10:81-98

Stokes MA, Smiley TL (1996) An introduction to tree-ring dating. University of Arizona Press, Tucson, AZ

Walters GE, Wilderbuer TK (2000) Decreasing length at age in a rapidly expanding population of northern rock sole in the eastern Bering Sea and its effect on management advice. J Sea Res 44:17-26

Wells BK, Field JC, Thayer JA, Grimes CB and others (2008) Untangling the relationships among climate, prey and top predators in an ocean ecosystem. Mar Ecol Prog Ser 364: 15-29

Wilderbuer TK, Nichol DG (2008) Northern rock sole. In: Stock

Editorial responsibility: Stylianos Somarakis,

Heraklion, Greece assessment and fishery evaluation report for the groundfish resources of the eastern Bering Sea and Aleutian Islands, Sect 7. North Pac Fish Mgmt Council, Anchorage, AK, p 707-776

Wilderbuer TK, Walters GE, Bakkala RG (1992) Yellowfin sole, Pleuronectes asper, of the eastern Bering Sea: biological characteristics, history of exploitation, and management. Mar Fish Rev 54:1-18

Wilderbuer TK, Hollowed AB, Ingraham WJ Jr., Spencer PD, Conners ME, Bond NA, Walters GE (2002) Flatfish recruitment response to decadal climatic variability and ocean conditions in the eastern Bering Sea. Prog Oceanogr 55: 235-247

Wilderbuer TK, Nichol DG, Ianelli J (2007a) Yellowfin sole. In: Stock assessment and fishery evaluation report for the groundfish resources of the Bering Sea/Aleutian Islands regions, Sect 4. North Pac Fish Mgmt Council, Anchorage, AK, p 447-512

Wilderbuer TK, Nichol DG, Spencer PD (2007b) Alaska plaice. In: Stock assessment and fishery evaluation report for the groundfish resources of the Bering Sea/Aleutian Islands regions, Sect 9. North Pac Fish Mgmt Council, Anchorage, AK, p 955-998

Wolter K, Timlin MS (1998) Measuring the strength of ENSO events - how does 1997/98 rank? Weather 53:315-324

Yamaguchi DK (1991) A simple method for crossdating increment cores from living trees. Can J Res 21:414-416

Submitted: March 17, 2010; Accepted: June 2, 2010

Proofs received from author(s): August 16, 2010 